Brazil and biodegradable detergents

from Bruce Handler, Rio de Janeiro

The Brazilian Congress is studying a proposal to ban the manufacture of non-biodegradable detergents in this country, which is slowly waking up to the problems of pollution. The bill, which orders detergent makers to produce only non-polluting products, has passed the House Constitution and Justice Committee. It still must win the approval of the entire House, the Senate and the President to become law, however. Observers in Brasilia say the chances are good, in view of other recent indications that Brazil is abandoning its one-time policy of development at any price in favour of one that shows more concern for protection of the environment.

The detergent bill came as a result of a recent invasion of foul-smelling white foam that drifted off the Tiete River in the south-eastern part of the country and literally covered the Sao Paulo suburb of Santana do Parnaiba. The tropical town looked as if it had been hit by a freak snowstorm. Environmental experts were unanimous in blaming excess amounts of nonbiodegradable detergents that had been dumped into the river as the principal cause.

Concern over the Santana do Parnaiba incident was expressed as far away as Argentina, because the polluted Tiete empties into the ParanaPlate river basin. Because of Brazil's relative lack of concern about pollution until now, it may be prohibitively expensive to implement the detergent bill, even if it is passed quickly. Brazil at present imports all the benzine distillates needed to make biodegradable detergents, and because of a disastrous balance-of-payments situation caused by the high price of foreign crude oil, the government has ordered a drastic cutback on all but the most essential imports. The situation is even more pessimistic when one takes into account the fact that detergents are responsible for only a small percentage of water pollution in Brazil.

In August, President Ernesto Geisel signed a decree saying that all industries in Brazil must control pollution and giving the federal government the power summarily to close factories that foul the envinronment. This is quite a change from Brazil's position on pollution just a few years ago, when it told an international conference on the environment: "A country that has not yet reached satisfactory living standards cannot sidetrack its resources for pollution control."
The new decree does not mean, however, that this fast industrialising nation of 110 million people is going to become a paragon of environmental protection overnight. In fact, many pollution-conscious people here felt the immediate purpose of Geisel's decree was to stop state and local government from cracking down too hard and too fast on polluters, and thereby interfering with national development plans.

Cabinet ministers who suggested the anti-pollution measure to the president noted that although Brazil has an "acute" industrial pollution problem, the government must be careful "not to disorganise productive activities or cause social unrest." This seemed to be fancy wording for the problem of citizens in several Brazilian cities who have shown themselves to be at their wits' end because of pollution-and who would take to the streets in protest, if public demonstrations were not illegal under the military-controlled regime here.

A typical case occurred recently in the industrial town of Contagem outside Belo Horizonte, Brazil's third largest city. There, a cement factory whose smokestacks spew out over 100 tons of particles a day on local residents' houses had been promising for years to install pollution control equipment but never did. The people of Contagem complained that the factory was responsible not only for the white dust that covered everything in sight but also for widespread respiratory ailments.

Mayor Newton Cardoso finally ordered the factory closed. He said that "the human being must always be the focus of the government's attention." State police were sent out to make sure the plant's executives began shutting down production equipment, to comply with a deadline the mayor had set. In addition, the DOPS-the muchfeared political police-went to the cement factory after hearing reports that townspeople were going to hold a demonstration there to celebrate Mayor Cardoso's decision.

Then the presidential decree came out. A judge rescinded the mayor's order, on the grounds that local authorities could no longer singlehandedly shut down factories. The cement plant continues to operate, although its owners have promised to install anti-air pollution devices in 1976.

Paulo Nogueira Neto, who holds the recently created federal post of special secretary for the environment in Brazil, summed up the dilemma: "The important thing is not to pollute. But we also cannot ignore the economic side of the problem." $\mathrm{He}$ added that the new presidential decree "makes it clear that pollution control is obligatory and that there will be no loosening up."

Brazil has made remarkable economic progress since a developmentminded but politically repressive government took power in 1964. But it has paid a high price in ecological terms.

Pollution in Sao Paulo, the nation's largest city, has become so bad that a leading department store now stocks anti-pollution masks-in adults' and children's sizes. Sao Paulo's last mayor won applause from the populace when he temporarily closed a polluting cement factory there. But this led to a political fight with the governor, and the mayor lost his job. The factory is open again, and the particle fallout is as bad as ever.

Local authorities in the southern state of Rio Grande do Sul succeeded in closing down a foul-smelling cellulose factory that had been built by a big Norwegian pulp and paper manufacturer. But that factory is now in business again. The Norwegians sold their share of the undertaking to private Brazilian interests, and an influential retired Army general was installed as president of the company.

Federal Representative Jose Roberto Faria Lima, a supporter of the bill to ban n o n-biodegradable detergents, made this comment: "It's too bad the Tiete River had to become covered with foam before the need was shown for a law requiring the production of biodegradable detergents in this country. Anti-pollution plans and even the President's decree don't do any good. Simply saying: 'It's against the law to pollute' doesn't stop pollution".

\section{Coal standard}

\section{from Vera Rich}

DONETSK, in the Ukrainian SSR, has been accepted as the standard coalfield by the Eighth International Congress of Stratigraphic and Carboniferous Geology, which met recently in Moscow. The phenomena of the Donetsk field will be used as a basis for a unified international scale to be used in prospecting and establishing the boundaries of coal fields. The scale, which was proposed by a team of geologists from Britain, France, the USA and the Soviet Union, is at present at the draft stage. Nevertheless, the acceptance of Donetsk as the standard seems unlikely to be changed by further discussions, since this field is unique in giving a clear and detailed picture of the history of the whole of the Carboniferous period (345-280 Myr BP). Although Donetsk was selected on the basis of its geology, this coalfield has a history which may serve as a promising augury for international cooperation. As its original name of Uzhovka indicates, it was first opened up (1869-1870) by a Welsh mining expert by the name of Hughes. 